\title{
FAKTOR-FAKTOR YANG MEMPENGARUHI KEPUTUSAN PEMBELIAN PADA UKM SENTRA BANDENG KELURAHAN TAWANG MAS SEMARANG
}

\author{
Ratih Hesty Utami Puspitasari ${ }^{1}$, Rr. Hawik Ervina Indiworo ${ }^{2}$ \\ Universitas PGRI Semarang
}

Email koresponden: ratihhhesty@upgris.ac.id ${ }^{1}$

\begin{abstract}
The marketing ability of a company can affect its financial capabilities. One of the company's benefits can be generated from the demand for products and / or services, and other business functions will not run if there is no demand. a company must obtain revenue if it wants profit. One of the elements to get income is from marketing products and / or services. The marketing mix is a collection of controlled tactical marketing tools that companies combine to produce the responses they want in the target market. The marketing mix consists of all the things a company can do to influence the demand for its products. These possibilities can be grouped into four groups. Among them are Products (Price), Price (Price), Place (Place), and Promotion (Promotion). In this study 100 respondents were used. Determination of sample size using simple random techniques. Data were analyzed using the Multiple Regression Analysis method. Data processing using the SPSS program. The purpose of this study was to determine the factors that influence purchasing decisions at UKM Sentra Bandeng Tawang Mas Semarang. SME entrepreneurs must maintain the implementation of important factors that determine the performance of their businesses, while still making improvements to the factors that are still lacking in implementation, in order to get better performance.
\end{abstract}

Keywords: purchase decision, price, packaging, brand

\section{A. PENDAHULUAN}

Sasaran pembangunan ekonomi jangka panjang diarahkan untuk menciptakan ekonomi yang kokoh dan seimbang, yaitu struktur ekonomi dengan titik berat pada industri maju yang didukung oleh pertanian, perkebunan, perikanan yang tangguh. Untuk itu proses industrialisasi lebih dimantapkan guna mendukung perkembangan industri senagai penggerak utama dalam peningkatan laju pertumbunhan ekonomi dan peningkatan lapangan pekerjaan. pembangunan industri diupayakan untuk meningkatkan nilai tambah guna memperluas lapangan kerja dan kesempatan berusaha menyediakan barang dan jasa yang bermutu dengan harga yang bersaing dipasaran, serta menunjang pembangunan daerah.

Industri nasional di Indonesia membutuhkan peran Usaha Kecil Menengah (UKM) untuk menunjang perekonomian nasional, menyerap tenaga kerja, memberikan pemerataan hasil pembangunan dan menanggulangi kemiskinan. Pemerintah memiliki beberapa kebijakan strategis yang diimplementasikan dalam berbagai program untuk mendukung kemajuan UKM di Indonesia. Usaha Mikro Kecil di arahkan oleh pemerintah untuk memiliki 
keunggulan dalam bidang pemanfaatan sumber daya alam dan masyarakat lingkungan sekitar, misalnya seperti perkebunan, peternakan, perikanan, perdagangan, restoran dan tanaman pangan.

Menurut Hafsah (2004) pengembangan UKM perlu mendapatkan perhatian yang besar baik dari pemerintah maupun masyarakat agar dapat berkembang lebih kompetitif bersama pelaku ekonomi lainnya. Kebijakan pemerintah diharapkan dapat mendukung tumbuh kembangnya UKM di Indonesia. Peran pemerintah perlu ditingkatkan dalam memperkuat daya saing UKM di samping mengembangkan kemitraan usaha yang saling menguntungkan antara pengusaha besar dengan pengusaha kecil, serta meningkatkan kualitas sumber daya manusia pelaku UKM.

Faktor-faktor yang paling menentukan pengembangan dan pertumbuhan usaha UKM, dikemukakan Lasceviva (2004) sebagai berikut, yang pertama adalah sektor yaitu perusahaan yang beroperasi pada sector kegiatan ekonomi yang berbeda memiliki pertumbuhan yang berbeda. Pada level agregat, perusahaan dalam sektor pengolahan dan jasa umumnya tumbuh yang lebih tinggi dari pada yang beroperasi disektor perdagangan. Faktor yang kedua adalah lokasi, UKM yang berlokasi di daerah pedesaan tumbuh kurang cepat daripada yang berlokasi di daerah perkotaan, demikian juga yang berlokasi dalam pasar tradisional, distrik komersial; atau disepanjang jalan tumbuh lebih cepat daripada yang berlokasi di dalam rumah. Ketiga yaitu regional, UKM yang berada di suatu daerah kabupaten yang tingkat pendapatan perkapitanya tinggi tumbuh lebih cepat dari kabupaten yang tingkat pendapatan perkapita penduduknya rendah.

Perkembangan teknologi saat ini memberikan dampak terhadap kehidupan manusia terutama dalam bidang usaha. Persaingan usaha sudah semakin sengit, mengingat pelaku usaha semakin meningkat. Banyak usaha- usaha yang bahkan tidak sejenis, dapat menjadi pesaing yang tangguh untuk menggoyang bisnis perusahaan. Oleh sebab itu, perusahaan harus dapat melakukan kegiatan pemasaran dengan cermat untuk menghadapi persaingan dan perkembangan usaha yang dalam hal ini adalah usaha UKM. Selain itu, kegiatan pemasaran juga dapat menunjang perolehan laba atau profit perusahaan.

Kesuksesan perusahaan dari segi finansial tidak lepas dari kemampuan perusahaan dalam memasarkan produk dan atau jasa nya. Jika permintaan terhadap produk dan atau jasa perusahaan tidak ada, maka fungsi manajemen lain seperti operasional, akuntansi, keuangan dan sumber daya manusia tidak dapat berjalan sebagaimana mestinya. Perusahaan harus pendapatkan laba atau profit untuk kelangsungan bisnisnya. Salah satu faktor yang dapat 
meningkatkan profit perusahaan adalah dengan memanfaatkan bauran pemasaran. Bauran pemasaran atau marketing mix adalah kumpulan dari alat- alat pemasaran yang dimanfaatkan oleh perusahaan guna menghasilkan respon yang diinginkan perusahaan pada target market yang ditentukan. Bauran pemasaran terdiri dari produk, harga, tempat dan promosi. Bauran pemasaran juga digunakan oleh perusahaan untuk meningkatkan permintaan produk dan atau jasa yang diproduksi oleh perusahaan.

Produk (Product) merupakan segala sesuatu yang dapat ditawarkan kepada pasar agar menarik perhatian, akuisisi, penggunaan, atau konsumsi yang dapat memuaskan suatu keinginan atau kebutuhan. Produk dapat berupa barang yang berwujud atau tangible dan barang yang tidak berujud atau intangible. .Bauran produk (Product Mix) adalah rangkaian dari semua lini produk dan barang yang dijual oleh penjual tertentu. Suatu bauran produk perusahaan mempunyai empat dimensi penting yaitu lebar, panjang, kedalaman, dan konsistensi.

Kelompok usaha yang perlu memperoleh dorongan dari luar berupa pelatihan dan pendampingan usaha ini termasuk di dalamnya adalah kelompok usaha yang mengolah bahan makanan dari ikan bandeng. Namun, dari segi aspek produksi kedua usaha tersebut masih terbatas karena hanya untuk memenuhi di sekeliling lokasi usaha dan juga dipasarkan pada momen-momen tertentu antara lain arisan ibu-ibu, pengajian minggu pagi, pasar tiban, dan sebagainya. Oleh karena itu, untuk memperluas cakupan pangsa pasarnya, kegiatan pendampingan pemasaran dirasa perlu untuk dilakukan dengan tujuan agar produk ini lebih dikenal konsumen, dan dapat menginformasikan keunggulan sebuah produk usaha.

Pengembangan suatu produk melibatkan pada apa manfaat dari yang akan di tawarkan produk tersebut. Atribut - atribut produk seperti kemasan, dan merek dipandang sebagai faktor yang mempengaruhi keputusan pembelian konsumen, yang mana semakin baik atribut sebuah produk, maka akan semakin besar peluang produk tersebut untuk diminati oleh para konsumen. Dalam melakukan pengambilan keputusan pembelian suatu produk, tentunya hal yang dibutuhkan adalah keyakinan dan rasa percaya diri yang kuat. Sikap yang positif menciptakan rasa percaya diri konsumen/ pelanggan atas keputusan pembelian.

Daerah Tawang Mas dan Daerah Krobokan merupakan salah satu kelurahan yang terletak di Kecamatan Semarang Barat. Selain sebagai pusat produksi tempe, Krobokan juga sebagai pusat produksi ikan asap dan bandeng presto. Pusat produksi pengasapan ikan dan bandeng presto terletak di RW 08 dan RW 09. Produksi ini semakin berkembang dengan dibantu oleh Dinas Perikanan dalam penyedian cerobong asap untuk produksi pengasapan 
ikan dan beberapa alat lain yang mendukung dan meningkatkan hasil produksi. Hasil produksi dipasarkan di beberapa tempat seperti pasar terdekat maupun ke beberapa kantor. Selain dipasarkan langsung, beberapa UKM juga menerima pesanan dalam jumlah banyak.

Ikan yang diolah merupakan ikan terpilih. Beberapa jenis ikan yang diolah menjadi ikan asap diantaranya manyung, tongkol, pari, songot, dan lain sebagainya. Untuk hasil olahan ikan bandeng sendiri diantaranya bandeng duri lunak, otak-otak bandeng, pepes bandeng duri lunak, bandeng cabut duri, abon bandeng, tahu bakso isi bandeng dan abon duri bandeng. Harga yang ditawarkan cukup terjangkau, dengan kualitas rasa yang tidak kalah dengan produk-produk terkenal yang banyak dipasarkan di luar. Sebagai oleh-oleh makanan khas Semarang banyak pilihan produk olahan bandeng yang dapat dibawa pulang dengan pilihan harga yang beragam dan rasa yang berkualitas yang dapat ditemukan di Kelurahan Tawang Mas dan Krobokan Kecamatan Semarang Barat (ukm.krobokansemarang.web.id). Pada pengrajin bandeng duri lunak Tawang Mas dan krobokan Semarang kendala pada aspek pemasaran sangat tinggi. Seperti pada tingkat pemasaran yang hanya sampai di pasar tradisional. Itu hanya sebatas sampai pada pasar tradisional krobokan semarang.

Tabel 1. Data UMKM Bandeng Presto Kota Semarang 2017/2018

\begin{tabular}{|c|c|c|}
\hline Wilayah & Jumlah produsen & Kapasitas produksi per hari \\
\hline Tawang Mas/Krobokan & 21 & 630 \\
\hline Bamban kerep & 12 & 210 \\
\hline Tambak mulyo & 31 & 232 \\
\hline Mangkang & 2 & 80 \\
\hline Pandean lamper & 1 & 100 \\
\hline Tambak rejo & 2 & 80 \\
\hline TOTAL & $\mathbf{6 9}$ & $\mathbf{1 . 3 3 2}$ \\
\hline
\end{tabular}

Sumber: BPS, 2018

Dari data di atas dari total 69 produsen bandeng presto di kota semarang dapat menghasilkan kapasitas produksi per hari 1.332 ekor bandeng presto. Segala strategi untuk mencapai hasil penjualan yang tinggi harus ditempuh para pengolah bandeng presto, demi memenangkan daya saing diantara mereka. Strategi pemasaran adalah alat fundamental yang direncanakan untuk mencapai tujuan perusahaan dengan mengembangkan keunggulan bersaing yang berkesinambungan melalui pasar yang dimasuki dan program pemasaran yang dipergunakan untuk melayani pasar sasaran tersebut.

Bisnis UKM Bandeng presto menjadi primadona di kota Semarang, persaingan usaha terjadi antara pengusaha besar dan pengusaha kecil. Aspek pemasaran merupakan hal yang diunggulkan dalam memasarkan produk UKM Bandeng Presto. Misalnya toko- toko di pusat oleh- oleh Jalan Pandanaran Semarang. Produk yang dijual di toko tersebut berasal dari 
bandeng presto yang diproduksi oleh pengusaha besar di Semarang. Dengan mengamati fenomena tersebut, maka sangat diperlukan strategi pemasaran untuk UKM Bandeng Presto.

Strategi pemasaran harus disesuaikan dengan skala bisnis yang ada dan calon konsumen yang dijadikan pasar sasaran. Dengan demikian, dapat diketahui strategi pemasaran yang lebih efektif dan efisien guna meningkatkan daya saing dan pada akhirnya dapat meningkatkan kesejahteraan para pengolah bandeng presto tersebut. Kurangnya sarana pemasaran di tingkat UMKM maka produk bandeng presto milik UMKM sebagian besar berakhir di pasar tradisional.

Hanya sebagian kecil UKM yang bisa menembus pasar moden dan ekspor ke mancanegara. Sedangkan perilaku masyarakat perkotaan pada masa sekarang ini kecenderungan lebih besar ke pasar modern. Maka diperlukan sarana pemasaran yang lebih baik lagi. Terutama pemasaran dengan sistem word of mouth, sehingga produk UMKM bandeng presto khususnya di Kota Semarang dapat lebih diterima pangsa pasarnya lebih luas lagi. Berdasarkan latar belakang tersebut diatas, maka masalah dalam penelitian ini adalah kurangnya sarana pemasaran pada UKM Sentra Bandeng Kelurahan Tawang Mas Semarang, sehingga pertanyaan penelitiannya adalah bagaimana meningkatkan sarana pemasaran pada UKM Sentra Bandeng Kelurahan Tawang Mas Semarang.

\section{B. TELAAH PUSTAKA}

Produk merupakan salah satu elemen kunci dalam keseluruhan penawaran pasar. Merencanakan bauran pemasaran dapat dimulai dengan merumuskan penawaran yang memberikan nilai bagi pelanggan sasaran. Penawaran ini menjadi dasar bagi perusahaan dalam membangun hubungan yang menguntungkan dengan pelanggan (Kotler dan Amstrong, 2006). Produk yang disediakan oleh perusahaan harus sesuai dengan kebutuhan pelanggan dan dapat memuaskan pelanggan sasaran. Perusahaan harus dapat mengidentifikasi produk yang dibutuhkan oleh pelanggan nya.

Strategi penentuan harga dapat berpengaruh signifikan dalam pemberian value kepada konsumen dan mempengaruhi image produk, serta keputusan konsumen untuk membeli, Lupiyoadi (2013). Seperti misalnya jika perusahaan ingin memberikan image produk menjadi barang mewah, maka harga juga dapat menentukan. Harga juga berhubungan dengan pendapatan dan turut mempengaruhi supply atau marketing channels. Akan tetapi, yang paling penting adalah keputusan dalam harga harus konsisten dengan strategi pemasaran secara keseluruhan. Maka dapat disimpulkan bahwa harga adalah merupakan faktor yang 
dapat mempengaruhi konsumen dalam membeli suatu produk / jasa yang diinginkan, atau sebagai alat tukar untuk mengukur suatu nilai uang yang terkandung dalam suatu barang atau jasa, sedangkan yang dipakai sebagai alat pengukur adalah uang.

Peran kemasan semakin penting dalam memasarkan produk - produk perusahaan. Adanya kemasan dalam strategi pemasaran suatu produk juga cukup membantun pelanggan untuk mengidentifikasi produk perusahaan kita dengan produk pesaing. Kemasan bisa menciptakan nilai khusus bagi pelanggan, sehingga kemasan juga bisa dikategorikan sebagai alat pemasaran (Kotler dan Keller, 2009). Pengemasan dalan kegiatan pemasaran dapat berupa kegiatan perlindungan terhadap produk, penambahan nilai produk dan memberikan manfaat lebih kepada pelanggan. Pengemasan dapat menjadi hal yang penting baik bagi penjual maupun konsumen.

Kotler dan Keller (2009) dalam bukunya menyatakan bahwa merek adalah nama, istilah, tanda, simbol, rancangan, atau kombinasi diantaranya, yang dimaksutkan untuk mengidentifikasikan barang atau jasa dari satu penjual atau sekelompok penjual dan untuk mendiferensiasikan mereka dari barang atau jasa pesaing. Merek dapat didefinisikan sebagai kombinasi dari atribut-atribut, dikomunikasikan melalui nama atau simbol yang dapat mempengaruhi proses pemilihan suatu produk atau layanan di benak konsumen. Dalam pengertian lain, merek juga sering diartikan sebagai nama dan atau simbol seperti logo, trademark dan sekumpulan desain unik yang mengindentifikasi produk atau jasa dari penjual dan membedakannya dari produk dan jasa milik pesaing (Kotler, 2003). Dengan adanya merek, pelanggan akan lebih mudah mengidentifikasi produk perusahaan. Merekdapat memberikan jaminan kepada pelanggan, misalnya jaminan keamanan, jaminan kualitas, dan jaminan nilai yang akan diterima oleh pelanggan.

Keputusan pembelian adalah keputusan konsumen mengenai preferensi atas merekmerek yang ada didalam kumpulan pilihan (Kotler dan Keler, 2009). Keputusan pembelian merupakan hal yang dipengaruhi oleh perilaku konsumen. Perilaku konsumen merupakan unsur penting dalam kegiatan pemasaran suatu produk yang perlu dipahami oleh perusahaan, karena perusahaan pada dasarnya tidak mengetahui mengenai apa yang ada dalam pikiran seorang konsumen pada waktu sebelum, sedang, dan setelah melakukan pembelian produk tersebut. Dalam keputusan pembelian, umumnya ada lima macam peranan yang dapat dilakukan seseorang. Kelima peran tersebut meliputi (Kotler dan Amstrong, 2008): pemprakarsa (initiator), pemberi pengaruh (influencer), pengambil keputusan (decider), pembeli (buyer), pemakai (user). 
Dalam penelitian ini terdapat 4 hipotesis yang akan diteliti yaitu:

H1: Ada pengaruh harga terhadap keputusan pembelian pada pada pelanggan UKM Bandeng Presto Tawang Mas Semarang.

H2: Ada pengaruh Kemasan terhadap keputusan pembelian pada pada pelanggan UKM Bandeng Presto Tawang Mas Semarang.

H3 : Ada pengaruh merk terhadap keputusan pembelian pada pada pelanggan UKM Bandeng Presto Tawang Mas Semarang.

H4: Ada pengaruh harga, kemasan, dan merek terhadap keputusan pembelian pada pada pelanggan UKM Bandeng Presto Tawang Mas Semarang.

\section{Kerangka Pikir Teoritis}

Berdasarkan telaah pustaka yang telah dilakukan sebelumnya, maka kerangka pemikiran teoritis dalam penelitian ini adalah:

\section{Gambar 1. Kerangka Pikir Teoritis}

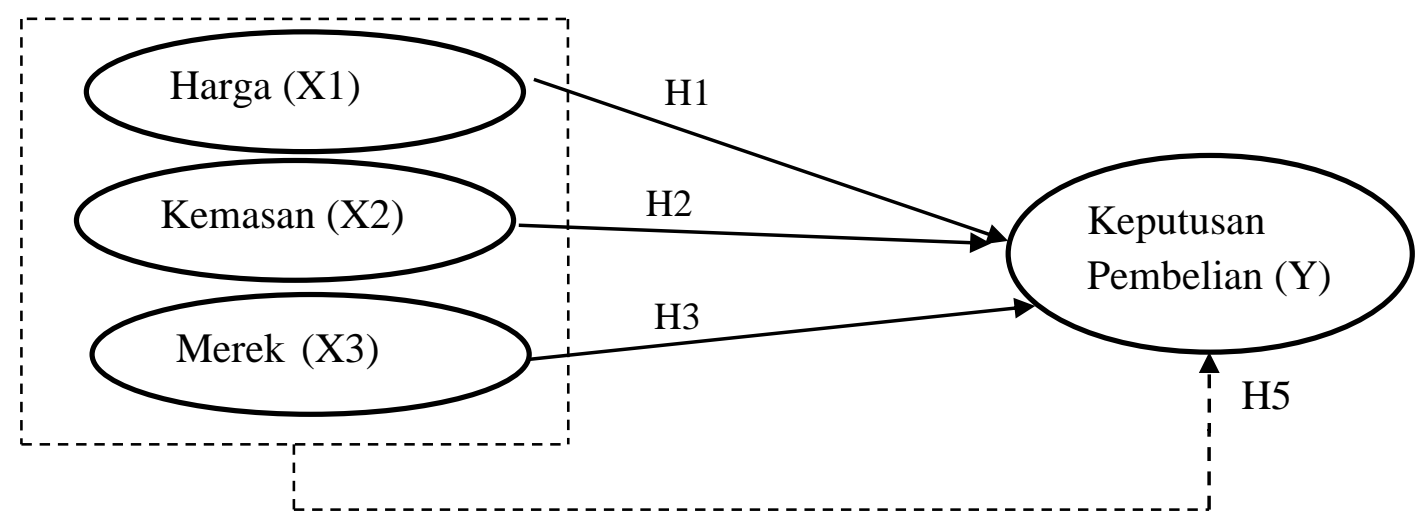

Keterangan :

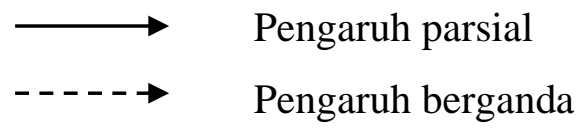

Sumber :Fandos dan Flavian (2006), Buchari Almam (2005), Kotler dan Keller (2009), Rangkuti (2009), Kotler dan Keller (2009)

\section{METODOLOGI PENELITIAN}

\section{Metode Analisis Deskriptif}

Menurut Nazir (2013:43) "analisis deskriptif adalah metode dalam meneliti status sekelompok manusia, suatu objek, suatu set kondisi, suatu system pemikirsn, stsupun dustu kelas peristiwa pada masa sekarang. Tujuan dari analisis deskriptif ini adalah untuk membuat 
deskripsi, gambaran atau lukisan secara sistematis, factual dan akurat mengenai fakta - fakta, sifat - sifat serta hubungan antar fenomena yang diselidiki”.

Sedangkan menurut Whitney dalam Nazir (2013), "metode deskriptif adalah pencarian fakta dengan interpretasi yang tepat. Penelitian deskriptif mempelajari masalah masalah dalam masyarakat serta tata cara yang berlaku dalam masyarakat dan situasi - situasi tertentu termasuk tentang hubungan, kegiatan - kegiatan, sikap - sikap, pandangan pandangan, serta proses - proses yang sedang berlangsung dan pengaruh - pengaruh dari suatu fenomena".

\section{Persamaan regresi linier berganda}

Analisis pengaruh harga, kemasan, dan merek, terhadap keputusan pembelian. Yang dapat diketahui dengan menggunakan analisis regresi linier berganda dengan rumus sebagai berikut :

Keterangan: $Y=a+b_{1} X_{1}+b_{2} X_{2}+b_{3} X_{3}+e$

$\mathrm{Y} \quad=$ Keputusan Pembelian sebagai variabel terikat

$\mathrm{X}_{1} \quad=$ Harga, sebagai variabel bebas

$\mathrm{X}_{2}=$ Kemasan, sebagai variabel bebas

$\mathrm{X}_{3} \quad=$ Merek, sebagai variabel bebas

$\mathrm{a} \quad=$ Konstanta

$\mathrm{b}_{1}, \mathrm{~b}_{2}=$ Koefisien regresi yang dicari (Sudjana, 2014)

e $\quad=\operatorname{error}($ Sudjana, 2014)

\section{HASIL DAN PEMBAHASAN}

Dalam sampel penelitian yang telah diperoleh, terdapat identitas responden berdasarkan usia atau umur responden dan berdasarkan jenis kelamin. Berdasarkan hal tersebut, dibawah ini merupakan deskripsi profil responden berdasarkan usia sebagai berikut:

Tabel 2. Karakteristik Responden Berdasarkan Usia

\begin{tabular}{|c|c|c|}
\hline Umur (tahun) & Jumlah Responden & Presentasi \\
\hline 20-27 Tahun & 20 & $20 \%$ \\
\hline 28-35 Tahun & 45 & $45 \%$ \\
\hline 36-43 Tahun & 13 & $13 \%$ \\
\hline 44-51 Tahun & 12 & $12 \%$ \\
\hline 52-60 Tahun & 10 & $10 \%$ \\
\hline Jumlah & 100 & $100 \%$ \\
\hline
\end{tabular}

Sumber: Hasil Analisis Data (2018) 
Dalam Tabel 2 diatas, dapat diketahui bahwa untuk umur responden yang terbanyak adalah umur 28- 35 tahun yaitu sebanyak 45 orang atau 45\%, diikuti dengan usia responden 20- 27 tahun sebanyak 20 orang atau $20 \%$.

Tabel 3. Karakteristik Responden Berdasarkan Jenis Kelamin

\begin{tabular}{|c|c|c|}
\hline Jenis Kelamin & Jumlah Responden & Presentasi \\
\hline Laki-Laki & 42 & $42 \%$ \\
\hline Wanita & 58 & $58 \%$ \\
\hline Jumlah & 100 & $100 \%$ \\
\hline
\end{tabular}

Sumber: Hasil Analisis Data (2018)

Berdasarkan tabel 3. dapat diketahui bahwa responden terbanyak adalah berjenis kelamin wanita yaitu sebanyak 58 orang (58\%) dibanding laki-laki yang hanya 42 orang (42\%). Hal ini menunjukkan bahwa jenis kelamin wanita sebagai proporsi yang lebih besar dibanding pelanggan laki-laki.

Analisis regresi digunakan dalam menguji seberapa besar pengaruh antara harga, kemasan, merk dan keputusan pembelian. Data regresi, maka dapat disajikan persamaan regresi yaitu sebagai berikut:

$$
Y=2,651-0,287 X_{1}+0,259 X_{2}+0,434 X_{3}
$$

Berdasarkan persamaan regresi diatas dapat dijelaskan sebagai berikut:

a. Persamaan regresi memiliki konstanta sebesar 2,651. Hal tersebut menunjukkan bahwa variabel Harga, Kemasan dan Merk dengan kondisi konstan atau X=0, maka Keputusan Pembelian 2,651 satuan skor.

b. $X_{1}$ (harga) koefisien regresi sebesar -0,287 mempunyai pengaruh yang negatif terhadap $\mathrm{Y}$ (keputusan pembelian). Artinya apabila harga turun sebesar satu-satuan, maka hal tersebut dapat meningkatkan keputusan pembelian sebesar 0,287 satuan.

c. $X_{2}$ (kemasan) koefisien regresi sebesar 0,259 mempunyai pengaruh yang positif terhadap Y (keputusan pembelian). Artinya apabila kemasan semakin naik sebesar satu-satuan, maka hal tersebut dapat menigkatkan keputusan pembelian sebesar 0,259 satuan.

d. $X_{3}$ (merk) koefisien regresi sebesar 0,434 mempunyai pengaruh yang positif terhadap $\mathrm{Y}$ (keputusan pembelian). Artinya apabila merk semakin naik sebesar satu-satuan, maka hal tersebut dapat meningkatkan keputusan pembelian sebesar 0,434 satuan.

\section{Pengujian Hipotesis}

Untuk meyakinkan bahwa masing-masing variabel yaitu: harga, kemasan dan merk terhadap keputusan pembelian, dilakukan pengujian secara parsial. Dari perhitungan 
komputer menggunakan program SPSS yang telah di analisis dapat di lihat pada tabel diperoleh nilai $t_{\text {hitung }}$ sebagai berikut:

Tabel 4. Analisis Parsial

\begin{tabular}{|l|l|l|l|}
\hline Variabel & $t_{\text {hitung }}$ & $t_{\text {tabel }}$ & Keterangan \\
\hline$X_{1}$ & 4,121 & 1,984 & Ada pengaruh signifikan \\
\hline$X_{2}$ & 3,895 & 1,984 & Ada pengaruh signifikan \\
\hline$X_{3}$ & 2,401 & 1,984 & Ada pengaruh signifikan \\
\hline
\end{tabular}

Sumber: Hasil Analisis Data (2018)

Uji t merupakan pengujian koefisien regresi secara individu.

\section{Uji Hipotesis Variabel Harga $\left(X_{1}\right)$}

Menentukan Hipotesis nol (Ho) dan Hipotesis alternatif (Ha):

Ho: Tidak ada pengaruh yang signifikan antara Harga terhadap keputusan pembelian pada pelanggan UKM Bandeng Presto Tawang Mas Semarang.

Ha: Ada pengaruh harga terhadap keputusan pembelian pada pada pelanggan UKM Bandeng Presto Tawang Mas Semarang.

Dengan menggunakan tingkat signifikan kehandalan sebesar $95 \%$ atau $\alpha=2,5 \%$ uji dua sisi dengan tingkat kebebasan $\mathrm{df}=\mathrm{n}-\mathrm{k}-1=100-3-1=96$ diketahui $t_{\text {hitung }}$ sebesar 4,121 dan $t_{\text {tabel }}=1,984$. kriteria keputusan pembelian dapat dilakukan dengan cara perbandingan nilai $t_{\text {hitung }}$ dengan $t_{\text {tabel }}$. karena $t_{\text {hitung }} 4,121>t_{\text {tabel }} 1,984$. Maka Ho ditolak dan Ha diterima. Hal ini berarti bahwa hipotesis yang meyatakan ada pengaruh yang signifikan antara harga terhadap keputusan pembelian pada pada pelanggan UKM Bandeng Presto Tawang Mas Semarang terbukti berpengaruh, serta pengaruhnya signifikan dengan nilai sig. sebesar $0,003<0,05$.

\section{Uji Hipotesis Variabel Kemasan $\left(X_{2}\right)$}

Menentukan Hipotesis nol (Ho) dan Hipotesis alternatif (Ha):

Ho: Tidak ada pengaruh yang signifikan antara Kemasan terhadap keputusan pembelian pada pada pelanggan UKM Bandeng Presto Tawang Mas Semarang

Ha: Ada pengaruh Kemasan terhadap keputusan pembelian pada pada pelanggan UKM Bandeng Presto Tawang Mas Semarang.

Dengan menggunakan tingkat signifikan kehandalan sebesar $95 \%$ atau $\alpha=2,5 \%$ uji dua sisi dengan tingkat kebebasan $\mathrm{df}=\mathrm{n}-\mathrm{k}-1=100-3-1=96$ diketahui $t_{\text {hitung }}$ sebesar 3,895 dan $t_{\text {tabel }}=1,984$. kriteria keputusan pembelian dapat dilakukan dengan cara perbandingan nilai 
$t_{\text {hitung }}$ dengan $t_{\text {tabel }}$. karena $t_{\text {hitung }} 3,895>t_{\text {tabel }} 1,984$. Maka Ho ditolak dan Ha diterima.

Hal ini berarti bahwa hipotesis yang menyatakan ada pengaruh yang signifikan antara kemasan terhadap keputusan pembelian pada pada pelanggan UKM Bandeng Presto Tawang Mas Semarang terbukti berpengaruh, serta pengaruhnya signifikan dengan nilai sig. sebesar $0,003<0,05$.

\section{Uji Hipotesis Variabel Merk $\left(X_{3}\right)$}

Menentukan Hipotesis nol (Ho) dan Hipotesis alternatif (Ha):

Ho: Tidak ada pengaruh yang signifikan antara merk terhadap keputusan pembelian pada pada pelanggan UKM Bandeng Presto Tawang Mas Semarang

Ha: Ada pengaruh merk terhadap keeputusan pembelian pada pada pelanggan UKM Bandeng Presto Tawang Mas Semarang.

Dengan menggunakan tingkat signifikan kehandalan sebesar $95 \%$ atau $\alpha=2,5 \%$ uji dua sisi dengan tingkat kebebasan $\mathrm{df}=\mathrm{n}-\mathrm{k}-1=100-3-1=96$ diketahui $t_{\text {hitung }}$ sebesar 2,401 dan $t_{\text {tabel }}=1,984$. Kriteria keputusan pembelian dapat dilakukan dengan cara perbandingan nilai $t_{\text {hitung }}$ dengan $t_{\text {tabel }}$. karena $t_{\text {hitung }} 2,401>t_{\text {tabel }} 1,984$. Maka Ho ditolak dan Ha diterima. Hal ini berarti bahwa hipotesis yang meyatakan ada pengaruh yang signifikan antara merk terhadap keputusan pembelian pada pada pelanggan UKM Bandeng Presto Tawang Mas Semarang terbukti berpengaruh, serta pengaruhnya signifikan dengan nilai sig. sebesar $0,000<0,05$

\section{Pengujian Secara Berganda}

Pengujian hipotesis antara variabel harga, kemasan dan merk terhadap keputusan pembelian. Pengujian ini dimaksudkan untuk mengetahui apakah variabel-variabel penjelas yang digunakan dalam model secara bersama-sama mempunyai pengaruh atau tidak terhadap variabel yang ingin dijelaskan dengan menggunakan uji F. pengujian ini dilakukan untuk menguji apakah pengaruh $X_{1}, X_{2}, X_{3}$ terhadap Y secara bersama-sama.

Tabel 5. Pengujian Berganda (dengan signifikansi $\alpha=5 \%$ )

ANOVA ${ }^{\mathrm{a}}$
\begin{tabular}{|l|l|l|r|r|r|r|}
\hline \multicolumn{2}{|l|}{ Model } & Sum of & & & \\
\hline 1 & Squares & df & Mean Square & F & Sig. \\
\hline & Regression & 59.080 & 3 & 11.816 & 37.110 & $.000^{\mathrm{b}}$ \\
& Residual & 10.793 & 96 & .109 & & \\
& Total & 69.873 & 99 & & & \\
\hline
\end{tabular}

a. Dependent Variable: FT 
Tabel 6. Hasil uji F

\begin{tabular}{|l|l|l|}
\hline$f_{\text {hitung }}$ & $f_{\text {tabel }}$ & Keterangan \\
\hline 37,110 & 2,70 & Ada pengaruh signifikan \\
\hline
\end{tabular}

Sumber: Data hasil SPSS (2018)

Uji F dapat digunakan untuk menguji signifikansi pengaruh dari variabel $\mathrm{X}$ terhadap Variabel Y.

Ho : $\beta 1, \beta 2, \beta 3=0$, artinya tidak ada pengaruh yang signifikan dari harga, kemasan dan merk terhadap variabel keputusan pembelian pada pada pelanggan UKM Bandeng Presto Tawang Mas Semarang.

Ha : $\$ 1, \beta 2, \beta 3>0$, artinya ada pengaruh yang signifikan dari harga, kemasan dan merk terhadap variabel keputusan pembelian pada pelanggan UKM Bandeng Presto Tawang Mas Semarang.

Kriteria keputusan pembelian dapat dilakukan dengan cara perbandingan nilai $f_{\text {hitung }}$ dengan $f_{\text {tabel }}$. karena $f_{\text {hitung }}>f_{\text {tabel }}(37,110>2,70)$ maka harga, kemasan dan merk secara bersama-sama berpengaruh signifikan terhadap keputusan pembelian, hal ini berarti Ho ditolak dan Ha diterima.

\section{Koefisien Determinasi $\left(R^{2}\right)$}

Dari hasil analisis dengan menggunakan SPSS diperoleh kontribusi antara variabel harga, kemasan dan merek terhadap keputusan pembelian. Dari hasil perhitungan regresi dapat diketahui bahwa Adjusted R Square yang diperoleh sebesar 0,705, hal tersebut berarti artinya bahwa variabel harga, kemasan dan merk terhadap keputusan pembelian sebesar $70,5 \%$. Sedangkan sisanya $29,5 \%$ itu adalah variabel lain yang tidak di teliti dalam penelitian ini.

\section{E. KESIMPULAN}

Industri UKM merupakan industri yang saat ini memiliki potensi besar di Indonesia. Adanya dukungan dari pemerintah, masyarakat dan swasta dapat membuat industri UKM di Indonesia semakin berkembang. Salah satu industri UKM di Indonesia adalah UKM Sentra Bandeng di Kelurahan Tawang Mas Semarang. Pada sentra bandeng tersebut, terdapat masalah yaitu kurangnya sarana pemasaran yang ada. Sehingga dalam penelitian ini dibahas mengenai harga, kemasan dan merek, dalam meningkatkan minat beli konsumen Sentra Bandeng di Kelurahan Tawang Mas Semarang. 
Berdasarkan penelitian yang telah dilakukan, diperoleh hasil bahwa harga, kemasan dan merek berpengaruh terhadap keputusan pembelian. Di mana variabel harga berpengaruh negatif terhadap keputusan pembelian, artinya jika harga naik, maka keputusan pembelian konsumen akan turun. Untuk variabel kemasan, jika semakin menarik kemasan produk, maka semakin tinggi minat beli konsumen terhadap produk bandeng tersebut. Selain variabel harga dan kemasan, merek juga berpengaruh positif terhadap keputusan pembelian konsumen.

Koefisien determinasi dalam penelitian ini adalah sebesar 70,5\%. Hal tersebut berarti bahwa variabel harga, kemasan dan merek dapat mempengaruhi keputusan pembelian sebesar $70,5 \%$, sedangkan sisanya sebesar $29,5 \%$ dipengaruhi oleh hal- hal lain yang tidak di teliti dalam penelitian ini. Dengan adanya hasil penelitian tersebut maka dapat disimpulkan bahwa variabel harga, kemasan dan merek merupakan hal yang penting untuk diperhatikan dalam memasarkan UKM sentra bandeng di lingkungan Tawang Mas Semarang.

\section{DAFTAR PUSTAKA}

Buchari Alma,. 2005. Manajemen Pemasaran dan Pemasaran Jasa. Cetakan. 5. Bandung: CV Alfabeta.

Fandos, C. dan Flavian. 2006. Intrinsic and Extrinsic Quality Attributes, Loyalty and Buying Intention: An Analysis for a PDO Product. Journal of British Food. 108(8):646-662.

Hafsah, M.J. 2004. Upaya Pengembangan Usaha Kecil dan Menengah (UKM). Jurnal Infokop Nomor 25 Tahun XX

Lupiyoadi, Rambat. 2013. Manajemen Pemasaran Jasa. Jakarta: Salemba Empat.

Nazir, Moh. 2014. Metode Penelitian. Bogor: Ghalia Indonesia

Kotler, Philip \& A.B Susanto. 2000. Manajemen pemasaran di indonesia analisis perencanaan implementasi dan pengendalian. Jakarta : Salemba Empat

Kotler, Philip. 2009. Manajemen pemasaran, Edisi ke-13. Indonesia: PT. Gelora Aksara Pratama.

Kotler, Philip dan Gary Amstrong. 2006. Prinsip-Prinsip Pemasaran, Edisi12 Jilid 1. Jakarta: Erlangga

Kotler, Philip dan Kevin Lane Keller. 2009. Manajemen Pemasaran, Edisi 13 Jilid 1. Jakarta: Erlangga 